\title{
Awareness of knowledge about the problem of human papillomavirus infections and HPV vaccination in a group of female students beginning their studies at universities in Lublin
}

\begin{abstract}
Introduction. HPV infection is one of the most common type of sexually transmitted infections and it is a significant epidemiological problem all over the world. The risk of infection persistence and its progression to pathological, precancerous lesions depends on HPV type. Vaccinations against HPV virus are one of the elements of the prophylactic program and allow for early detection of cervical cancer.

Aim. Aim of the study was analysis of awareness of problems of human papillomavirus infections and cervical cancer prevention, including vaccinations against HPV among female students commencing studies in Lublin.

Material and methods. The research group included 400 women selected at random, all starting their studies at five universities in Lublin. The research group was supposed to show some general knowledge of the problem of cervical cancer among young women. It was also to define how many of them benefited from the prophylaxis of getting a vaccination against HPV. The scientific tool was individually elaborated survey questionnaire. Obtained study results were then subject to statistical analysis.

Results. The majority of respondents were not vaccinated against HPV - only $2.5 \%$ of the surveyed confirmed that they had been vaccinated. The surveyed students most frequently evaluated their knowledge on prevention of HPV cervical cancer as poor. The surveyed who admitted having information about HPV and cervical cancer prophylaxis during their classes at school significantly more frequently had high level of knowledge than women who claimed not to obtain such information at school ( $p=0.002$ ).

Conclusions. It might make sense to conduct planned comparative studies in the centers practicing population vaccinations among girls aged 12-13 and not practicing such primary prophylaxis with cytological follow-ups. It may allow to elaborate the effective model of cervical cancer prophylaxis based on early educational activities, both on primary and secondary prophylaxis.
\end{abstract}

Keywords: HPV infections, cervical cancer, HPV vaccination, knowledge about HPV.

DOI: $10.1515 /$ pjph-2016-0036

\section{INTRODUCTION}

HPV infection is one of the most common type of sexually transmitted infections and it is a significant epidemiological problem all over the world [1]. The majority of HPV infections are short-lived, asymptomatic, showing no clinical symptoms, $70 \%$ new infections resolve spontaneously within one or two years, $90 \%$ of them due to body's natural immune response $[2,3]$. The mean duration of HPV infection is 8 months but the probability of remission decreases with time (the longer the infection, the more difficult a spontaneous regression) $[3,4]$. Persistent infection with a high-risk type of HPV is the most significant risk factor for the development of cervical cancer $[3,5,6]$. The risk of infection persistence and its progression to pathological, precancerous lesions depends on HPV type. The most oncogenic of all high risk types is HPV 16. The cofactors influencing persistence of infection and the development of malignant transformations of the affected cells are, among others, cigarette smoking, higher fertility rate, deficiency of folic acid, ultraviolet radiation, older age, long-term use of oral contraceptives, immunity deficiency [1].

Vaccinations against HPV virus are one of the elements of the prophylactic program and early detection of cervical cancer [1]. Vaccinations against HPV human papillomavirus have been available on the Polish medical care market since 2006 when a quadrivalent Silgard vaccine by Merck was introduced. A year later a bivalent vaccine Cervarix by Glaxo Smith Kline was registered. The vaccines were approved for use at the same time as they were in other European countries. According to European Centre for Disease Prevention and Control (ECDC) experts in Europe the program of routine HPV vaccinations of adolescent girls was introduced in 19 of the 29 countries of the European Union/European Economic Area (EEA) and in the 10 countries a program of additional vaccinations was introduced simultaneously [7]. Conducting vaccination program does not exempt national teams from sustaining

\footnotetext{
${ }^{1}$ Diagnostic Techniques Unit, Faculty of Health Sciences of the Medical University in Lublin, Poland

${ }^{2}$ Chair and Department of Gynecology and Gynecological Endocrinology, Medical University in Lublin, Poland

${ }^{3}$ The Department of Obstetrics, Gynecology and Gynecological and Obstetric Nursing, Medical University in Lublin, Poland

${ }^{4}$ Graduate, Medical University in Lublin, Poland
} 
population-based cervical cytology examinations. It is estimated that about $80-90 \%$ women will have to do with this sexually transmitted infection at one point of their lives but only $3-4 \%$ of them will develop cervical cancer [8-10]. Cervical cancer is the second most frequent cancer and the third most mortal gynecological cancer in the world. From among more than 200 virus serotypes the most common are types 16 and 18 which account for about $70 \%$ cases of cervical cancer. Therefore, HPV vaccinations includes these two serotypes. In 2009 Polish Gynecological Society issued official recommendations on the use of HPV vaccinations [11]. HPV vaccinations in Poland are not a part of national vaccination program mainly because of their high price. The authorities of some communes and districts introduced HPV vaccinations implementing projects for girls aged 12-13. Individual awareness of the problem of human papillomavirus infections may affect unassisted decisions concerning vaccinations against human papillomavirus [12]. Examinations are conducted all over the world on the level of knowledge connected with the problem of HPV infection and the ways of acquiring this knowledge [13].

\section{AIM}

The aim of the study was to analyze the awareness of problems of human papillomavirus infections and cervical cancer prevention, including vaccinations against HPV among female students starting to study in Lublin 10 years after introduction of the primary prophylaxis of this infection on medical care market:

1. Determining how many of them have already had vaccinations

2. Is there a correlation between gynecology appointments and the fact of starting sexual activity versus the general knowledge on etiology and prophylaxis of cervical cancer?

3 . How does the fact of discussing these issues at school influence the level of knowledge on HPV and cervical cancer prevention?

\section{MATERIAL AND METHODS}

The research group included 400 women chosen at random, all commencing their studies at universities. Research for the sake of this work was conducted among the first year female students from five universities in Lublin qualifying for the analysis 80 properly filled questionnaires from each university: The Medical University, The University of Life Sciences, The John Paul II Catholic University, The Lublin University of Technology, Maria Curie-Skłodowska University, between November 2012 and May 2013.

The assumption was the choice of the research group that was supposed to show general knowledge on the problem of cervical cancer among young women. It was also to define how many of them benefited from the prophylaxis of getting HPV vaccination. Questionnaire was filled out by the students on their own after previously assuring them of research anonymity and the use of obtained data for scientific purposes. The respondents were also instructed on the manner of filling the questionnaire.

The scientific tool was an individually elaborated survey questionnaire. Guidelines by the European Organization for Research and Treatment of Cancer were used in its preparation [14].
Survey questionnaire included 30 questions, 4 of which regarded the characteristics of the investigated group and the remaining ones were detailed questions on human papillomavirus, prophylactic vaccinations against human papillomavirus - a yes/no type.

The results obtained in the study were subject to a statistical analysis. The values of the analyzed measurable parameters were presented with the use of mean value and standard deviation and for immeasurable ones with the use of amount and percentage. A $\chi^{2}$ test for homogeneity was used for unrelated qualitative features in order to detect differences between the compared groups. Significance level of $p<0.05$ was adopted showing statistically significant differences. Data base and statistical studies were conducted basing on STATISTICA 10.0 (StatSoft, Poland) computer software.

\section{RESULTS}

The surveyed students most frequently evaluated their knowledge on HPV cervical cancer prevention as poor $(n=168$; $42 \%)$ and $22.25 \%(n=89)$ of the investigated assessed their knowledge as very poor; $31.75 \%(n=127)$ respondents as good and only $4 \%(n=16)$ assessed it as very good.

The majority of respondents were not vaccinated against HPV $(n=390 ; 97.5 \%)$. Only $2.5 \%(n=10)$ of the surveyed confirmed they had been vaccinated. The surveyed who were vaccinated against HPV most frequently obtained information about the vaccination from their families or friends $(n=7 ; 70 \%)$ and less frequently from media $(n=2 ; 20 \%)$ and the medical staff $(\mathrm{n}=1 ; 10 \%)$. The non-vaccinated surveyed most frequently stated that they had not got HPV vaccination because of their lack of knowledge $(n=1 ; 10 \%)$, less frequently it was the price $(n=61 ; 15.64 \%)$, doubt as to the efficacy of the vaccine $(n=46 ; 11.79 \%)$ as well as health concerns $(n=10 ; 2.57 \%)$. As a result of the conducted statistical analysis it was stated that the surveyed who had previously had their gynecological appointments more frequently showed high level of general knowledge $(23.62 \%)$ than women who had never had gynecological appointments $(17.12 \%)$. However, the stated differences were not statistically significant $(\mathrm{p}=0.20)$, (Table 1$)$.

The investigations show that the surveyed who had their cytological examinations performed slightly more frequently overall had higher level of general knowledge (26.21\%), compared to women who had never had cytology performed $(18.43 \%)$. The stated differences were not statistically significant $(\mathrm{p}=0.19)$, (Table 2$)$.

TABLE 1. General assessment of the level of knowledge including any gynecology appointment.

\begin{tabular}{|c|c|c|c|c|}
\hline \multirow{3}{*}{$\begin{array}{l}\text { Gynecological } \\
\text { appointment }\end{array}$} & \multicolumn{3}{|c|}{ General level of knowledge } & \multirow{2}{*}{ Total } \\
\hline & low & average & high & \\
\hline & $\begin{array}{l}\text { n } \\
\%\end{array}$ & $\begin{array}{l}\text { n } \\
\%\end{array}$ & $\begin{array}{l}\text { n } \\
\%\end{array}$ & $\begin{array}{c}\text { n } \\
\text { \% }\end{array}$ \\
\hline \multirow{2}{*}{ Yes } & 53 & 141 & 60 & 254 \\
\hline & $20.87 \%$ & $55.51 \%$ & $23.62 \%$ & $100.00 \%$ \\
\hline \multirow{2}{*}{ No } & 39 & 82 & 25 & 146 \\
\hline & $26.71 \%$ & $56.16 \%$ & $17.12 \%$ & $100.00 \%$ \\
\hline \multirow{2}{*}{ Total } & 92 & 223 & 85 & 400 \\
\hline & $23.00 \%$ & $55.75 \%$ & $21.25 \%$ & $100.00 \%$ \\
\hline \multicolumn{5}{|c|}{ Statistical analysis : $\mathrm{Ch}^{2}=3.23 ; \mathrm{p}=0.2$} \\
\hline
\end{tabular}


TABLE 2. General assessment of knowledge including opinion whether they had their cytological examination performed.

\begin{tabular}{lcccc}
\hline \hline \multirow{2}{*}{$\begin{array}{c}\text { Cytological } \\
\text { examination }\end{array}$} & \multicolumn{3}{c}{ General level of knowledge } & \multirow{2}{*}{ Total } \\
\cline { 2 - 4 } & low & average & high & \\
\cline { 2 - 4 } & $\begin{array}{c}\mathbf{n} \\
\mathbf{\%}\end{array}$ & $\begin{array}{c}\mathbf{n} \\
\mathbf{0}\end{array}$ & $\begin{array}{c}\mathbf{n} \\
\mathbf{\%}\end{array}$ & $\begin{array}{c}\mathbf{n} \\
\mathbf{\%}\end{array}$ \\
\hline \multirow{2}{*}{ Yes } & 31 & 76 & 38 & 145 \\
\hline \multirow{2}{*}{ No } & $21.38 \%$ & $52.41 \%$ & $26.21 \%$ & $100.00 \%$ \\
\hline \multirow{2}{*}{ Total } & 61 & 147 & 47 & 255 \\
\hline & $23.92 \%$ & $57.65 \%$ & $18.43 \%$ & $100.00 \%$ \\
\cline { 2 - 4 } & 92 & 223 & 85 & 400 \\
\hline
\end{tabular}

TABLE 3. General assessment of the level of knowledge including opinion whether classes on HPV and cervical cancer prophylaxis were conducted at school.

\begin{tabular}{|c|c|c|c|c|}
\hline \multirow{4}{*}{$\begin{array}{c}\text { Classes on } \\
\text { HPV and } \\
\text { cervical cancer } \\
\text { prophylaxis }\end{array}$} & \multicolumn{3}{|c|}{ General level of knowledge } & \multirow{2}{*}{ Total } \\
\hline & low & average & high & \\
\hline & $\mathbf{n}$ & $\mathbf{n}$ & $\mathbf{n}$ & $\mathbf{n}$ \\
\hline & $\%$ & $\%$ & $\%$ & $\%$ \\
\hline \multirow{2}{*}{ Yes } & 11 & 43 & 28 & 82 \\
\hline & $13.41 \%$ & $52.44 \%$ & $34.15 \%$ & $100.00 \%$ \\
\hline \multirow{2}{*}{ No } & 81 & 180 & 57 & 318 \\
\hline & $25.47 \%$ & $56.60 \%$ & $17.92 \%$ & $100.00 \%$ \\
\hline \multirow{2}{*}{ Total } & 92 & 223 & 85 & 400 \\
\hline & $23.00 \%$ & $55.75 \%$ & $21.25 \%$ & $100.00 \%$ \\
\hline \multicolumn{5}{|c|}{ Statistical analysis : $\mathrm{Ch}^{2}=12.40 ; \mathrm{p}=0.002 *$} \\
\hline
\end{tabular}

A statistical analysis revealed that the surveyed who admitted having information about HPV and cervical cancer prophylaxis during their classes at school significantly more frequently had high level of knowledge in this sphere $(34.15 \%)$ than women who claimed not to obtain such information at school $(17.92 \%)$. The stated differences were statistically significant ( $\mathrm{p}=0.002)$, (Table 3$)$.

$50 \%$ of the surveyed $(n=200)$ did not know what the efficacy of HPV vaccination was, whereas $36.25 \%(n=145)$ of them correctly answered that it protected against the most frequent oncogenic types of HPV, while $6.75 \%(n=27)$ erroneously believed that the vaccination protected against the most frequent oncogenic types of HPV to a small extent and $7.00 \%(n=28)$ of the surveyed stated that it protected against all types of HPV.

The surveyed most frequently knew that receiving full HPV vaccine series did not allow to neglect cytological examinations $(\mathrm{n}=214 ; 53.50 \%)$, whereas $2.50 \%(\mathrm{n}=10)$ of the surveyed mistakenly believed that even half HPV vaccine series exempted them from undergoing medical examinations, $2.75 \%(n=11)$ of them stated that the vaccination fully protected against the disease and eliminated the need of having cytology performed while $41.25 \%(n=165)$ stated they had no idea.

\section{DISCUSSION}

Authors would like to draw attention to the low percentage of women vaccinated against HPV - among the investigated students only $2.5 \%(\mathrm{n}=10)$ used the opportunity to get vaccinated. The same data are quoted by Mastalerz-Migas et al. [15]. They show that only $2.4 \%$ of the women surveyed by them got vaccinated against HPV [15]. Such a low percentage of vaccinated women is probably the effect of comparatively short period of time between introduction of the vaccine into the Polish market till the time of the research. Currently, in some centers in Poland there are vaccinations for girls aged 12-13, reimbursed by the local authorities [16]. One of the regional centers promoting vaccinations against human papillomavirus is Lublin commune which has offered 12-year-old girls free vaccinations since 2010 [17]. In the years 2010-2013 2831 girls were vaccinated which was $41 \%$ population.

According to the studies of Mastalerz-Migas et al., all of the vaccinated women were informed about the possibility of HPV vaccination by a gynecologist or a family doctor [15]. According to the surveyed in this study only $10 \%$ respondents obtained information about vaccinations from medical staff. The majority acquired it from their families, friends or media. The analysis of questions about gynecology appointments and general knowledge on cervical cancer prevention with regard to having any gynecology appointment supports this observation. In the past, gynecological appointments did not increase general knowledge about HPV or cervical cancer prophylaxis in a statistically significant way. Cytological examination did not increase the awareness of threats associated with HPV infection either. It indicates that it is necessary for the medical staff to put a greater emphasis on giving patients clear and legible information about the problem of human papillomavirus and cervical cancer prevention including HPV vaccinations. All the more so, because in the group of non-vaccinated the surveyed stated the lack of knowledge about the vaccination to be the main reason of not getting the vaccination, while less frequently stated it was too expensive. Unger at al. also presented observations different from Mastalerz-Migas at al. while assessing the knowledge of 365 women aged 19-26. With the use of randomized, controlled studies they stated that less than half of the surveyed acquired their knowledge on HPV and vaccination from health care professionals and the main source of knowledge about human papillomavirus and vaccinations was television [12].

Gynecological examination is the most fundamental in diagnosing and treating gynecological disorders. According to data from the study on cancer incidence in the world, Cancer Disease Control Priorities of 2015 in the countries with low socio-economic status even $90 \%$ women never had gynecological examination. In highly-developed countriesevery $10^{\text {th }}$ woman had gynecology appointment [18]. Regular appointments considerably lower the risk of cancer and the risk of cervical cancer may be lowered by $80 \%$ in case of regular gynecology appointments and having cytological examinations performed every 2-3 years [19]. According to recommendations of American Cancer Society the first cytological examination should be performed by women 3 years after sexual initiation or at the age of 21 [20]. It was stated in own studies that more than half of the surveyed had already had a follow-up gynecology appointment. However, only every third of them had cytological examination performed. Reksa et al. conducted the studies on 234 women aged 19-76. They revealed that $6 \%$ respondents within a year before the research had a follow-up gynecology appointment and $39.5 \%$ of them had cytological examination, $29 \%$ of the surveyed admitted they had regular gynecology appointments whereas $10 \%$ of them said they had never had such appointment. It is consistent with the abovequoted data [18]. The studies also revealed, that as much as 
$29.9 \%$ of the surveyed never had cytological smear performed [21]. The studies of Charążka and Bieńkiewicz [10] conducted on 300 students of two Łódź universities revealed that $75 \%$ of them had already had their first gynecology appointment, however, they did not state what percentage had cytological examination performed. The researchers evaluated students' knowledge as insufficient. They evaluated knowledge of the surveyed about factors increasing the risk of cervical cancer as poor in $85.67 \%$ and good in $14.33 \%$. However, they evaluated knowledge about precancerous states and cancer as poor in $69 \%$ and good in $31 \%$. The following data may be related to results obtained in our analysis on the basis of which it was stated, that $64.25 \%$ respondents had poor and very poor knowledge of HPV and cervical cancer prevention and only every third of them $(35.75 \%)$ had good and very good knowledge which is also an unsatisfactory result.

Vaccinations against HPV within the scope of regional and national programs may allow the change in proportions of data quoted above. One of the tools in the program of KędzierzynKoźle commune are educational meetings with boys and girls in the age group qualifying for participation in the program. The meetings are carried out in the way adjusted to cognitive abilities of children in this age group and they become acquainted with such subjects as carcinogens and conditions favorable for the development of cancer, how vaccinations work, HPV virus - the risk of infection and its consequences, cervical cancer prophylaxis [16]. It is an essential prophylactic action as our own studies show the significance of education in this respect. The surveyed who admitted to get information about HPV and cervical cancer prevention during their classes at school significantly more frequently had high level of general knowledge in this respect $(34.15 \%)$ than women who claimed that they did not get such information at school $(17.92 \%)$. The stated differences were statistically significant $(\mathrm{p}=0.002)$.

\section{CONCLUSIONS}

The findings point that in the coming years it will make sense to conduct planned comparative studies in the centers practicing population vaccinations among girls aged 12-13 and not practicing such primary prophylaxis with cytological follow-ups. Such comparative analysis may allow to elaborate the effective model of cervical cancer prophylaxis based on early educational activities, primary and secondary prophylaxis.

\section{REFERENCES}

1. Rekomendacje Polskiego Towarzystwa Ginekologicznego dotyczące diagnostyki, profilaktyki i wczesnego wykrywania raka szyjki macicy Prz Menopauz. 2006;4:198-201.

2. Franco E, Villa L, Sobrinho J, et al. Epidemiology of acquisition and clearance of cervical human papillomavirus infection in women from a high-risk area for cervical cancer. J Infect Dis. 1999;180:1415-23.

3. Molano M, van der Brule A, Plummer M, et al. Determinants of clearance of human papillomavirus infections in Colombian women with normal cytology: a population-based, 5-year follow-up study. Am J Epidemiol. 2003;158:486-94.

4. Giuliano A, Harris R, Sedjo R, et al. Incidence, prevalence, and clearance of type-specific human papillomavirus infections: The Young Women's Health Study. J Infect Dis. 2002;186:462-9.

5. Schiffman M, Kjær S. Natural history of anogenital human papillomavirus infection and neoplasia. J Natl Cancer Inst Monogr. 2003;31:14-9.

6. Schlecht N, Platt R, Duarte-Franco E, et al. Human papillomavirus infection and time to progression and regression of cervical intraepithelial neoplasia. J Natl Cancer Inst. 2003;95:1336-43.

7. [www.ecdc.europa.eu/en/publications/publications/20120905_gui_hpv_ vaccine_updat.pdf]

8. Castle P, Wacholder S, Lorincz A, et al. A prospective study of high-grade cervical neoplasia risk among human papillomavirus-infected women. J Natl Cancer Inst. 2002;94:1406-14.

9. Workowski KA, Bolan GA. Centers for Disease Control and Prevention. Sexually transmitted diseases treatment guidelines, 2015. MMWR Recomm Rep. 2015;64(RR-03):84-93.

10. Charążka A, Bieńkiewicz A. Profilaktyka raka szyjki macicy w świadomości studentek. Zdr Publ. 2002;112:340-4.

11. Kotarski J, Basta A, Dębski R, et al. Rekomendacje Zespołu Ekspertów Polskiego Towarzystwa Ginekologicznego dotyczące szczepienia przeciwko zakażeniom HPV. Gin Pol. 2009;2:139-46.

12. Unger Z, Maitra A, Kohn J, et al. Knowledge of HPV and HPV vaccine among women ages 19 to 26. Womens Health Iss. 2015;S10493867(15)00078-X.

13. Almeida CM1, Tiro JA, Rodriguez MA, et al. Evaluating associations between sources of information, knowledge of the human papillomavirus, and human papillomavirus vaccine uptake for adult women in California. Vaccine. 2012;30:3003-8.

14. Johnson C, Aaronson N, Blazeby, et al. EORTC Quality of life group, Guidelines for Developing Questionnaire Modules, 4th editon; 2011.

15. Mastalerz-Migas A, Nowak A, Steciwko A. Wiedza i świadomość młodych kobiet w zakresie profilaktyki raka szyjki macicy. Fam Med Prim Care Rev. 2011;13(3):443-5.

16. Program profilaktyki zakażeń wirusem brodawczaka ludzkiego 2014 -2016 r, Wydział Polityki Mieszkaniowej, Spraw Socjalnych i Zdrowia UM Kędzierzyn Koźle, załącznik nr 1 do Programu Ochrony Zdrowia 2014-2016; [www.kedzierzynkozle.pl/bip]

17. [www.lublin.eu/mieszkancy/zdrowie/programyzdrowotne/szczepienia-hpv]

18. Denny L, Herrero R, Levin C, et al. Cervical Cancer. In: H. Gelband, P. Jha, R. Sankaranarayanan, S. Horton (ed). Cancer: Disease Control Priorities, Third Edition (Volume 3). Washington (DC): The International Bank for Reconstruction and Development/The World Bank. 2015;4.

19. Podlińska M, Bernacka M, Gotlib J. Próba oceny wpływu wieku na poziom wiedzy na temat raka szyjki macicy wśród pacjentek hospitalizowanych w oddziale położniczo-ginekologicznym. Pielęg XXI w. 2010;1-2:57-63.

20. Saslow D, Runowicz CD, Solomon D, et al. American Cancer Society guideline for the early detection of cervical neoplasia and cancer. American Cancer Society. CA Cancer J Clin. 2002;52:342-62.

21. Reksa D, Muszyńska A, Grotowska M, et al. Rak szyjki macicy - profilaktyka a świadomość społeczna. Fam Med Prim Care Rev. 2006;8:740-2.

\section{Corresponding author}

Gustaw Chołubek

Diagnostic Techniques Unit, Faculty of Health Sciences of the Medical

University in Lublin, Poland

tel: 502-581-676;

E-mail: g.cholubek@gmail.com 